\title{
Investigation and Study on Vegetation of Qinghai-Tibet Highway
}

\author{
Jiang Wei ${ }^{1,2, *}$, Wang $\mathrm{Qi}^{1,2}$, Shan Yonti ${ }^{1,2}$, Yin Jing ${ }^{1,2}$, Yang Peng ${ }^{1,2}$ \\ ${ }^{1}$ CCCC First Highway Consultants Co. Ltd., Xi'an 710065, China \\ ${ }^{2}$ Xi'an Zhongjiao Environmental Engineering Co., LTD, Xi'an, Shaanxi 710065, China
}

\begin{abstract}
Since the dominant species of original vegetation and the distribution pat terns of the bio-diversities are essential to vegetation recovery and restoration along the Qinghai-Tibet Highway. A vegetation survey was conducted on the Lhasa-Tuotuo River section of the Qinghai-Tibet Highway, and 30 sample points were set to analyze the vegetation community along the Highway. Analysis of vegetation Community along Highway. The results show that there are 18 families, 26 genera, and 32 species of plants in the Qinghai-Tibet Highway Corridor. Compared with the world, China, and Tibet, the plant families belong to $3.26 \%$ of the total in the world, $5.341 \%$ of the total in China and $8.491 \%$ of the total in Tibet, but the species only accounted for $0.542 \%$ of the total number of Tibetan plant species. The dominant species of flowering ground cover are Astragalus strictus, Potentilla, etc. the species richness reduced closely with the altitude, and more species in southward than in northward. The variation of vegetation community diversity index is not directly related to elevation, but related to microclimate change along the highway.
\end{abstract}

\section{Introduction}

Qinghai-Tibet Plateau is an unique natural geographical unit, known as the "third pole" of the earth, is "the total sheltered umbrella of all types of ecosystems in Southeast Asia"[1], is an important gene pool in the world, but also the birthplace of rivers in China and Southeast Asian countries, is the "water tower"[2] of our country and even Asia. Therefore, it has a great impact on the ecological security of our country and its surrounding countries.

The Qinghai-Tibet Highway crosses the center of the Qinghai-Tibet Plateau, and the vegetation along the line is inevitably affected by some degree during the construction and operation of the highway. The natural geography and climate of Qinghai-Tibet Plateau are unique, and the ecological environment is very fragile. Once disturbed and destroyed, it is difficult to restore[3-4], So the study of vegetation recovery along the highway is very important[5-8]. This paper takes the native flowering ground cover vegetation along the Qinghai-Tibet Highway Corridor as an object, and conducts vegetation research on the Qinghai-Tibet Highway Corridor, with a view to providing theoretical basis for the vegetation restoration and construction along the proposed Qinghai-Tibet Highway Corridor and the entire Qinghai-Tibet Plateau.

\section{Study on area general situation}

The land forms along the Qinghai-Tibet Highway mainly include: Piedmont flood plains, high plains, and river valleys, with an average elevation of more than $4000 \mathrm{~m}$. The highways have unique climatic characteristics of the Qinghai-Tibet Plateau with various types. The northern part is a plateau temperate arid climate zone and the central region is formed above $4000 \mathrm{~m}$ Climate characteristics of the plateau sub-frigid zone. The multi-year average minimum temperature is -14.5 $\sim-17.4{ }^{\circ} \mathrm{C}$, and the annual precipitation gradually decreases from $480 \mathrm{~mm}$ (Lhasa) to the north along the corridor to $40 \mathrm{~mm}$ (Golmud). The rainfall is unevenly distributed throughout the year, mainly concentrated in May to September, accounting for the entire year. The precipitation is $97 \%$, and the water system along the Qinghai-Tibet Highway is developed. The soil types are: alpine meadow soil, alpine grassland soil, etc. This paper takes the Lhasa-Qinghe section of the Qinghai-Tibet Highway as the main research object and conducts vegetation surveys.

\section{Research method}

\subsection{Investigation method and sample point layout}

The vegetation of flowering ground was investigated within $50 \mathrm{~m}$ on both sides of the highway along Lhasa-Tuotuo River section of Qinghai-Tibet Highway in August 2016, and the sample plot was $1 \times 1 \mathrm{~m}^{2}$. The sample plot was positioned with a GPS instrument and the surrounding environment characteristics detailed record.

\footnotetext{
*Corresponding author's e-mail: 305593947@qq.com
} 


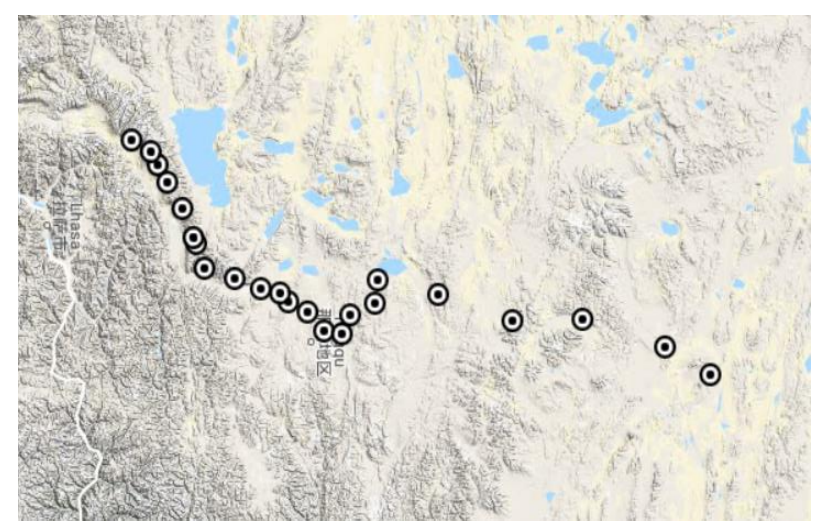

Figure 1 Vegetation survey line and sample plots

\section{2 data processing method}

SPSS 19.0 and EXCEL were used for data analysis and icon production. The analysis and calculation methods of vegetation survey data are as follows:

$$
S R=\frac{S-1}{\ln N}
$$

$\mathrm{SR}$ is species richness index; $\mathrm{S}$ is number of species; $\mathrm{N}$ is total number of individuals

$$
H=-\sum P i(\ln P i)(i=1,2,3, \ldots \ldots s)
$$

$\mathrm{H}$ is Shannon - Wiener index; $\mathrm{Pi}$ is the ratio of the number of individuals of the with species to the total number of individuals $\mathrm{N}$; $\mathrm{S}$ is number of species

$$
D=1-\sum P i \quad(i=1,2,3, \ldots \ldots s)
$$

$\mathrm{D}$ is Simpson index; $\mathrm{Pi}$ is the ratio of the number of individuals of the with species to the total number of individuals $\mathrm{N}$;

$$
E=\frac{-\sum P i(\ln P i)}{\ln S}(i=1,2,3, \ldots \ldots s)
$$

$\mathrm{E}$ is Pielou Evenness index; $\mathrm{Pi}$ is the ratio of the number of individuals of the ith species to the total number of individuals $\mathrm{N}$; $\mathrm{S}$ is number of species

\section{Results and analysis}

\subsection{Dominant species distribution}

The Qinghai-Tibet Highway Corridor covers different vegetation types, mainly including alpine grassland, alpine shrub, alpine meadow and swamp meadow, as well as cushion vegetation and sparse vegetation of Alpine flow stone slope.

The results showed that in the Lhasa-Tuotuo River section of the Qinghai-Tibet Highway corridor, there were a total of 18 families, 26 genera and 32 species of plants, which accounted for $3.226 \%$ of the world's total, $5.341 \%$ of China's total and $8.491 \%$ of Tibet's total. But the species only accounted for $0.542 \%$ of the total number of Tibetan plant species.

According to the dominant species in sampling place,

\begin{tabular}{|c|c|c|c|c|c|c|}
\hline \multirow{2}{*}{$\begin{array}{l}\text { Plot } \\
\text { number }\end{array}$} & \multirow{2}{*}{ stake number } & \multicolumn{3}{|c|}{ Geographical position } & \multirow{2}{*}{ Dominant species } & \multirow{2}{*}{$\begin{array}{l}\text { domina } \\
\text { nce }\end{array}$} \\
\hline & & $\mathbf{N}$ & $\mathbf{E}$ & Altitude & & \\
\hline 1 & $\mathrm{~K} 3832+900$ & $29^{\circ} 55^{\prime} 10^{\prime \prime}$ & $90^{\circ} 54^{\prime} 55^{\prime \prime}$ & $3944.0 \mathrm{~m}$ & $\begin{array}{l}\text { Astragalus strictus R. Grah. ex } \\
\text { Benth. }\end{array}$ & 0.551 \\
\hline 2 & K3821 & $30^{\circ} 32^{\prime} 11^{\prime \prime}$ & $91^{\circ} 19^{\prime} 32^{\prime \prime}$ & $4366.0 \mathrm{~m}$ & Potentilla bifurca $L$ & 0.455 \\
\hline 3 & $\mathrm{~K} 3804+150$ & $30^{\circ} 5^{\prime} 29^{\prime \prime}$ & $90^{\circ} 32^{\prime} 39^{\prime \prime}$ & $4288.0 \mathrm{~m}$ & $\begin{array}{l}\text { Ligularia rumicifolia } \\
\text { (Drumm).S.W.Liu.comb.nov. }\end{array}$ & 1.000 \\
\hline 4 & $\mathrm{~K} 3804+150$ & $30^{\circ} 5^{\prime} 29^{\prime \prime}$ & $90^{\circ} 32^{\prime} 39^{\prime \prime}$ & $4288.0 \mathrm{~m}$ & $\begin{array}{l}\text { Astragalus strictus R. Grah. ex } \\
\text { Benth. }\end{array}$ & 0.974 \\
\hline 5 & $\mathrm{~K} 3804+150$ & $30^{\circ} 5^{\prime} 29^{\prime \prime}$ & $90^{\circ} 32^{\prime} 39^{\prime \prime}$ & $4288.0 \mathrm{~m}$ & Anaphalis hancockii Maxim. & 1.000 \\
\hline 6 & $\mathrm{~K} 3800+200$ & $30^{\circ} 5^{\prime} 29^{\prime \prime}$ & $90^{\circ} 32^{\prime} 39^{\prime \prime}$ & $4339.6 \mathrm{~m}$ & $\begin{array}{l}\text { Arenaria densissima Wall. ex } \\
\text { Edgew et Hook. } f \text {. }\end{array}$ & 0.375 \\
\hline 7 & $\mathrm{~K} 3798+500$ & $30^{\circ} 15^{\prime} 51^{\prime \prime}$ & $90^{\circ} 38^{\prime} 51^{\prime \prime}$ & $4581.5 \mathrm{~m}$ & $\begin{array}{l}\text { Erigeron breviscapus (Vant.) } \\
\text { Hand. -Mazz. }\end{array}$ & 0.677 \\
\hline 8 & $\mathrm{~K} 3786+100$ & $30^{\circ} 12^{\prime} 56^{\prime \prime}$ & $90^{\circ} 37^{\prime} 32^{\prime \prime}$ & $4595.7 \mathrm{~m}$ & Urtica tibetica W. T. Wang & 0.476 \\
\hline 9 & $\mathrm{~K} 3786+100$ & $30^{\circ} 12^{\prime} 56^{\prime \prime}$ & $90^{\circ} 37^{\prime} 32^{\prime \prime}$ & $4595.7 \mathrm{~m}$ & Potentilla bifurca $L$ & 0.341 \\
\hline 10 & K3785 & $30^{\circ} 13^{\prime} 21^{\prime \prime}$ & $90^{\circ} 37^{\prime} 48^{\prime \prime}$ & $4611.7 \mathrm{~m}$ & $\begin{array}{l}\text { Astragalus strictus R. Grah. ex } \\
\text { Benth. }\end{array}$ & 0.550 \\
\hline 11 & K3776 & $30^{\circ} 16^{\prime} 13^{\prime \prime}$ & $90^{\circ} 43^{\prime} 25^{\prime \prime}$ & $4460.2 \mathrm{~m}$ & $\begin{array}{l}\text { Astragalus strictus R. Grah. ex } \\
\text { Benth. }\end{array}$ & 0.914 \\
\hline 12 & K3759 & $30^{\circ} 20^{\prime} 11^{\prime \prime}$ & $90^{\circ} 51^{\prime} 37^{\prime \prime}$ & $4256.4 \mathrm{~m}$ & Potentilla saundersiana Royle & 0.592 \\
\hline 13 & K3759 & $31^{\circ} 24^{\prime} 52^{\prime \prime}$ & $91^{\circ} 58^{\prime} 38^{\prime \prime}$ & $4460.0 \mathrm{~m}$ & Potentilla saundersiana Royle & 0.542 \\
\hline 14 & K3759 & $31^{\circ} 18^{\prime} 09^{\prime \prime}$ & $91^{\circ} 50^{\prime} 01^{\prime \prime}$ & $4594.5 \mathrm{~m}$ & Anaphalis hancockii Maxim. & 0.553 \\
\hline 15 & K3759 & $31^{\circ} 18^{\prime} 09^{\prime \prime}$ & $91^{\circ} 50^{\prime} 01^{\prime \prime}$ & $4460.0 \mathrm{~m}$ & Potentilla saundersiana Royle & 0.726 \\
\hline 16 & K3735 & $30^{\circ} 26^{\prime} 52^{\prime \prime}$ & $91^{\circ} 3^{\prime} 11^{\prime \prime}$ & $4247.5 \mathrm{~m}$ & $\begin{array}{l}\text { Astragalus strictus R. Grah. ex } \\
\text { Benth. }\end{array}$ & 0.539 \\
\hline 17 & $\mathrm{~K} 3710+800$ & $30^{\circ} 31^{\prime} 26^{\prime \prime}$ & $91^{\circ} 16^{\prime} 32^{\prime \prime}$ & $4313.7 \mathrm{~m}$ & Potentilla saundersiana Royle & 0.489 \\
\hline 18 & $\mathrm{~K} 3663+300$ & $31^{\circ} 46^{\prime} 38^{\prime \prime}$ & $91^{\circ} 36^{\prime} 02^{\prime \prime}$ & $4645.6 \mathrm{~m}$ & Braya rosea & 0.606 \\
\hline
\end{tabular}
the dominant flowering ground in the Lhasa-Tuoto River are Astragalus strictus and Potentilla, etc.

Tab 1 Dominant species analysis 


\begin{tabular}{|c|c|c|c|c|c|c|}
\hline 19 & $\mathrm{~K} 3656+600$ & $30^{\circ} 35^{\prime} 55^{\prime \prime}$ & $91^{\circ} 30^{\prime} 32^{\prime \prime}$ & $4650.7 \mathrm{~m}$ & $\begin{array}{l}\text { Anaphalis margaritacea (L.) } \\
\text { Benth. et Hook. } f .\end{array}$ & 0.194 \\
\hline 20 & $\mathrm{~K} 3638+700$ & $30^{\circ} 59^{\prime} 14^{\prime \prime}$ & $91^{\circ} 39^{\prime} 38^{\prime \prime}$ & $4735.2 \mathrm{~m}$ & $\begin{array}{l}\text { Anaphalis margaritacea (L.) } \\
\text { Benth. et Hook. } f \text {. }\end{array}$ & 0.311 \\
\hline 21 & $\mathrm{~K} 3622+600$ & $31^{\circ} 6^{\prime} 59^{\prime \prime}$ & $91^{\circ} 41^{\prime} 42^{\prime \prime}$ & $4644.4 \mathrm{~m}$ & $\begin{array}{l}\text { Astragalus strictus R. Grah. ex } \\
\text { Benth. }\end{array}$ & 0.308 \\
\hline 22 & K3612 & $31^{\circ} 9^{\prime} 33^{\prime \prime}$ & $91^{\circ} 46^{\prime} 14^{\prime \prime}$ & $4644.4 \mathrm{~m}$ & $\begin{array}{l}\text { Potentilla fruticose L. var. } \\
\text { pumila Hook. } f .\end{array}$ & 0.507 \\
\hline 23 & $\mathrm{~K} 3554+300$ & $31^{\circ} 32^{\prime} 24^{\prime \prime}$ & $91^{\circ} 59^{\prime} 59^{\prime \prime}$ & $4537.5 \mathrm{~m}$ & $\begin{array}{l}\text { Astragalus strictus R. Grah. ex } \\
\text { Benth. }\end{array}$ & 0.259 \\
\hline 24 & $\mathrm{~K} 3516+300$ & $31^{\circ} 10^{\prime} 15^{\prime \prime}$ & $91^{\circ} 45^{\prime} 33^{\prime \prime}$ & $4650.5 \mathrm{~m}$ & Ephedra minuta Florin & 0.661 \\
\hline 25 & K3500 & $31^{\circ} 45^{\prime} 39^{\prime \prime}$ & $91^{\circ} 46^{\prime} 23^{\prime \prime}$ & $4644.4 \mathrm{~m}$ & Anaphalis hancockii Maxim. & 0.502 \\
\hline 26 & K3444.50 & $31^{\circ} 10^{\prime} 49^{\prime \prime}$ & $91^{\circ} 42^{\prime} 54^{\prime \prime}$ & $4905.5 \mathrm{~m}$ & $\begin{array}{l}\text { Duchesnea indica (Andr.) } \\
\text { Focke }\end{array}$ & 0.778 \\
\hline 27 & K3378 & $31^{\circ} 35^{\prime} 33^{\prime \prime}$ & $91^{\circ} 51^{\prime} 45^{\prime \prime}$ & $5113.8 \mathrm{~m}$ & $\begin{array}{l}\text { Astragalus strictus R. Grah. ex } \\
\text { Benth. }\end{array}$ & 0.863 \\
\hline 28 & $\mathrm{~K} 3343+500$ & $32^{\circ} 11^{\prime} 21^{\prime \prime}$ & $91^{\circ} 42^{\prime} 37^{\prime \prime}$ & $4700.0 \mathrm{~m}$ & Potentilla saundersiana Royle & 0.424 \\
\hline 29 & K3169 & $34^{\circ} 6^{\prime} 12^{\prime \prime}$ & $91^{\circ} 20^{\prime} 58^{\prime \prime}$ & $4755.6 \mathrm{~m}$ & Potentilla bifurca $L$ & 0.378 \\
\hline 30 & K3169 & $34^{\circ} 6^{\prime} 12^{\prime \prime}$ & $91^{\circ} 20^{\prime} 58^{\prime \prime}$ & $5031.6 \mathrm{~m}$ & Anaphalis hancockii Maxim. & 0.562 \\
\hline
\end{tabular}

\subsection{Effects of elevation on vegetation index}

\subsubsection{Changes Species richness}

Due to the special ecological environment, there are basically no trees in the native vegetation along the Lhasa-Tuotuo River section of Qinghai-Tibet Highway, and the vegetation has a single life type. Shrubs also only appear in a few sample zones, and are mostly in the shape of cushion, with low species abundance, and most of the vegetation along the line is low herbaceous. Therefore, this paper calculated the richness of all plant species investigated, so as to fully reflect the impact of environmental gradient along the highway on vegetation distribution.

As can be seen from figur, there is a strong similarity between the variation law of species richness and the variation law of elevation, and the variation trend of species richness and elevation is basically the same. Therefore, elevation is the main factor affecting species richness. But the variation of species richness is much larger than the variation of altitude, indicating that species richness is not only influenced by altitude, but also by other factors.

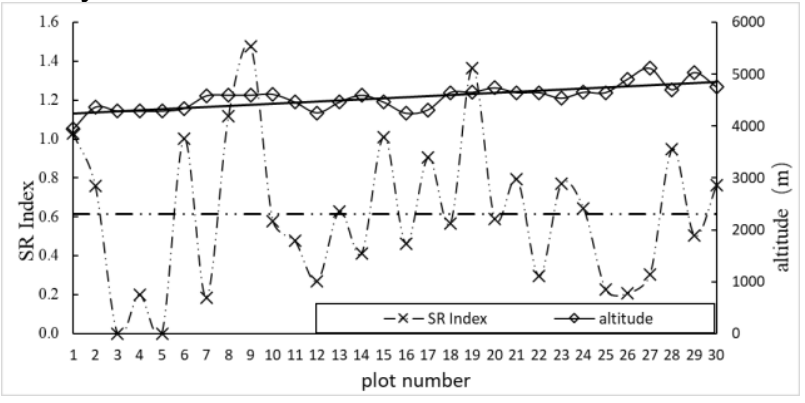

Fig 2 Species richness varies with altitude

\subsubsection{Changes species diversity and species evenness}

The vegetation diversity index along the Qinghai-Tibet Highway corridor shows a gradual increase from north to south, while the water and heat conditions along the corridor also show a gradual improvement from north to south, indicating that the main factor for the vegetation diversity index along the Qinghai-Tibet Highway corridor is the water and heat conditions. However, the differences in microclimate along the corridor due to topography and landform lead to differences in species diversity. For example, sample points $3 、 4$ and 5 are located in YangbaJin with an altitude of $4230 \mathrm{~m}$ and are in the draught with strong wind, large evaporation and low temperature. The growth environment of vegetation is relatively poor, resulting in a low diversity index of vegetation here. However, No.8-9 sample land (altitude: $4543 \mathrm{~m}$ ) is located in the Dang-Xiong River valley and has a high vegetation diversity index. The reason is that the water condition in the valley is better, so the vegetation growth condition is better. As can be seen from the trend line in the figure, the change trend of species diversity is not necessarily related to the change trend of altitude, but is more related to the microclimate along the corridor.

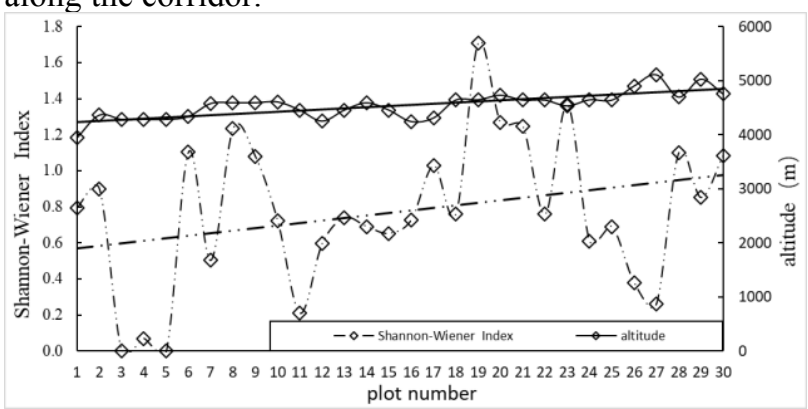

Fig 3 species diversity varies with altitude 


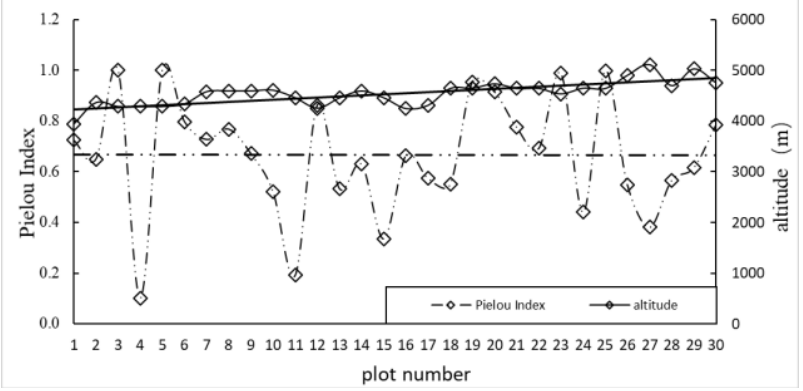

Fig 4 species evenness varies with altitude

\section{Conclusion}

(1) According to the vegetation survey of the Lassa-Tuotuo River section of the Qinghai-Tibet Highway corridor, there are total of 18 families, 26 genera and 32 species of plants, which account for $3.226 \%$ of the world's total, $5.341 \%$ of China's total and $8.491 \%$ of Tibet's total. However, the species only account for $0.542 \%$ of the total plant species in Tibet. The dominant species in the main flowering ground are Astragalus strictus, Potentilla bifurca, etc. With strong adaptability to the environment and strong reproduction ability of the Qinghai-Tibet plateau, the native dominant species with strong reproduction ability can be considered as the application of vegetation restoration species.

(2) According to the vegetation survey results, the species richness of the Lasa-Tuotuo River section showed a tendency of less in the north and more in the south, and gradually decreased with the elevation. The variation of vegetation community diversity index is not directly related to elevation, but is related to microclimate change along the corridor.

\section{Acknowledgments}

Authors wishing to acknowledge assistance or encouragement from colleagues, special work by technical staff or financial support from organizations should do so in an unnumbered Acknowledgments section immediately following the last numbered section of the paper.

\section{References}

1. Mo Shenguo, Zhang Baiping, Cheng Weiming, et al. Major Environmental Effects of the Tibetan Plateau[J]. PROGRESS IN GEOGRAPHY, 2004, 23(2): 88-96.

2. Lu Chunxia, Xie Gaodi, Cheng Shengkui, et al. The Tibetan Plateau as Water Tower[J]. JOURNAL OF MOUNTAIN SCIENCE), 2004(04):46-50.

3. Ma Shizhen, Chen Guichen, Pen Min, et al. The alpine steppe vegetation restoration process of fountainhead region of Yangtze River[J]. China Environmental Science, 2004, 24(2): 188-191.
4. Xu Wenxin, Zhou Yuke, et al. A Breakpoints based Spatio-temporal Analysis of Tibetan Plateau Vegetation[J]. Remote Sensing Technology and Application, 2019, 34(3): 667-676.

5. Wu Qingbo, Niu Fujun. Permafrost changes and engineering stability in Qinghai-Xizang Plateau[J]. SCIENCE CHINA PRESS, 2013, 58(2): 115-130.

6. Liu Zhenyuan, Zhang Jie, et al. Effects of vegetation degradation on atmospheric circulation over the Tibetan Plateau and its surrounding areas[J]. Acta Ecologica Sinica, 2018,38(1):132 142

7. Luo, Jiufu, Zhen Jingming, Zhou jinxin, et al. Analysis of the interspecific associations present in an alpine meadow community undergoing revegetation on the railway-construction affected land of the Qinghai-Tibet Plateau[J]. Acta Ecologica Sinica, 2016, 36(20)

8. Sun Yongning, Wang Jinchang Ham Qingjie,et al. The Alpine Vegetation and Soil Characters and Vegetation Recovery along the Golmud-Anduo Section of the Qinghai-Tibet Railway[J]. Journal of Desert Research, 2011, 31(4).

9. Yi Zuoming. Study of vegetation recovery along the Qinghai-Tibet railroad[D]. Beijing Forest University, 2007. 